\title{
PENGEMBANGAN BAHAN AJAR MENULIS RESENSI CERPEN BERBASIS LITERASI KRITIS BAGI SISWA SMA KELAS XI
}

\author{
Siti Latifah Mubasiroh, Endah Tri Priyatni, Gatut Susanto \\ Prodi Pendidikan Bahasa Indonesia, Universitas Negeri Malang \\ sitilatifahmubasiroh@gmail.com
}

\begin{abstract}
Abstrak
Literasi kritis dalam pembelajaran menulis resensi diperlukan untuk menumbuhkan kesadaran kritis bagi siswa untuk menemukan praktik sosial yang termuat dalam teks. Fenomena di lapangan menunjukkan bahwa pembelajaran menulis resensi belum mencapai level kritis. Oleh sebab itu, perlu dikembangkan bahan ajar yang dapat membantu siswa untuk menghasilkan resensi kritis dengan panduan yang jelas dan sesuai dengan level berpikir siswa. Penelitian ini bertujuan untuk menghasilkan bahan ajar menulis resensi cerpen berbasis literasi kritis yang memenuhi kelayakan isi, penyajian materi, keterbacaan, kegrafikaan, daya terap dan serap, kebermanfaatan, serta efektivitas bahan ajar dalam pembelajaran bagi siswa SMA kelas XI. Penelitian ini merupakan jenis penelitian pengembangan. Data diperoleh dari hasil validasi produk dan komentar validator serta responden. Hasil validasi dosen ahli, guru, dan respon siswa menunjukkan bahwa produk yang dikembangkan termasuk dalam kategori layak diimplementasikan dalam pembelajaran menulis resensi kritis cerpen.
\end{abstract}

Kata kunci: Bahan ajar, menulis resensi, literasi kritis

\begin{abstract}
Critical literacy in the review writing learning is needed to foster critical awareness for students to find social practices contained in the text. Phenomenon in the field shows that the review writing learning has not reached yet the critical level. Therefore, it is necessary to develop teaching materials that can help students to produce critical reviews with clear guidelines and in accordance with their thinking level. This study aims to produce teaching materials for writing short story reviews based on critical literacy that meet the appropriateness of content, presentation of material, readability, graphics, applicability and absorption, usefulness, and effectiveness of teaching materials in learning for high school students in grade XI. The type of research is a developmental. Data obtained from the results of product validation and validator and respondent comments. The results of the validation of expert lecturers, teachers, and student responses indicate that the products developed are included in the appropriate category to be implemented in learning to write short story critical reviews.
\end{abstract}

Key words: Teaching materials, writing reviews, critical literacy 


\section{PENDAHULUAN}

Keberadaan bahan ajar sangat memengaruhi keberhasilan proses pembelajaran. Bahan ajar yang inovatif mutlak dibutuhkan sebagai pendongkrak motivasi peserta didik dalam belajar. Hal ini didukung oleh pernyataan Prastowo (2012:14) bahwa bahan ajar yang monoton menimbulkan kebosanan peserta didik dalam mengikuti proses pembelajaran, sehingga proses tersebut menjadi tidak efektif dan efisien. Oleh sebab itu, perlu disusun bahan ajar yang tidak monoton. Menurut Burden \& Byrd (2013:28), bahan ajar yang inovatif adalah yang dapat menggali potensi siswa, menjawab kebutuhan siswa dari berbagai kompetensi, mempertimbangkan pengalaman yang dimiliki siswa, memotivasi siswa untuk berkembang dengan berbagai tugas, menggunakan berbagai macam model penilaian, dan adakalanya menguji kemampuan siswa dengan sesuatu di luar ekspektasinya. Untuk mencapai beberapa karakteristik bahan ajar yang demikian, Prastowo (2012:17) menyampaikan bahwa bahan ajar yang inovatif dapat dibuat dengan memanfaatkan, mengolah, dan mengkreasikan berbagai sumber belajar yang ada. Sumber belajar tersebut dapat berupa buku paket, modul, LKS, dan benda nyata yang dapat digunakan sebagai sumber belajar.

Asia and The Pacific Programme of Educational Innovation for Development (1985:53) mengemukakan tentang ciri-ciri buku ajar yang berkualitas tinggi diarahkan pada

(1) meet the needs of children at their level,

(2) meet the needs of the curriculum and, through it, the country,

(3) meet the needs and expectacions of teachers and parents,

(4) be sufficiently durable and attractive to be useful in terms of the above needs,

(5) be available on time and in sufficient quantity to achieve the foregoing aims.

Berdasarkan pernyataan tersebut, dapat dipahami bahwa buku ajar yang memiliki kualitas tinggi adalah yang (1) sesuai dengan karakteristik siswa, (2) sesuai dengan kurikulum, (3) sesuai dengan tujuan yang ingin dicapai guru dan orang tua, (4) cukup bisa bertahan lama dan menarik untuk digunakan, serta (5) memberikan banyak kesempatan bagi siswa untuk mencapai tujuan ke depan. Untuk menciptakan produk buku ajar yang berkualitas, unsur-unsur esensial dalam bahan ajar menurut Prastowo (2012:28), meliputi petunjuk belajar, 
kompetensi yang akan dicapai, informasi pendukung, latihan-latihan, petunjuk kerja atau lembar kerja, dan evaluasi. Beberapa unsur tersebut hanyalah panduan dasar yang berkenaan dengan substansi buku teks sebagai bahan ajar. Dengan demikian, kualitas bahan ajar yang disusun sangat bergantung pada kreativitas penyusun bahan ajar.

Pembelajaran bahasa termasuk salah satu bidang yang sangat memerlukan kehadiran bahan ajar. Ghazali (2013:73) menyatakan bahwa dalam pembelajaran bahasa, guru harus memutuskan apa yang harus diajarkan, bagaimana menentukan urutan dari materi bahasa, teknik pengajaran apa yang harus digunakan, dan bagaimana mengevaluasi hasil pembelajaran. Salah satu keterampilan berbahasa adalah menulis. Menulis merupakan keterampilan yang kompleks dengan mengoptimalkan kreativitas dan ekspresi diri dalam wujud tulisan. Seperti yang disampaikan oleh Applebee (2000:90) bahwa menulis merupakan sesuatu yang rumit, bergantung pada interrelationship (hubungan timbal balik) antara membaca, menulis, menyimak, dan berbicara, sebagaimana asumsi yang mengatakan bahwa keterampilan menulis dimiliki secara alamiah oleh siswa. Dalam hal ini Kuncoro (2009:4) menambahkan bahwa setiap orang memiliki bakat menulis, hanya perlu berlatih dan meningkatkan keterampilan menulis untuk berbagai keperluan. Dengan demikian, kehadiran buku ajar yang inovatif diharapkan menjadi sumber dan media belajar yang memotivasi serta mendukung siswa untuk menguasai keterampilan menulis.

Sikap kritis dalam mengkaji karya sastra sebagai bahan menulis resensi dapat dilakukan dengan menerapkan teori kritik sastra. Kritik sastra ialah studi sastra yang berusaha menyelidiki karya sastra dengan menganalisis, menginterpretasi, memberi komentar, dan memberikan penilaian (Pradopo, 2002:34-35; Pradotokusumo, 2008:55). Kritik sastra berfungsi untuk memberikan uraian dan penerangan tentang karya sastra yang konkret, baik mengenai struktur, isi, maupun nilai karya sastra tersebut. Dengan demikian, penguraian (analisis), penafsiran (interpretasi), dan penilaian (evaluasi) menjadi aspek utama kritik sastra yang saling erat berkaitan (Pradopo, 2002:38; Pradopo, 
2013:93). Untuk mendukung keberfungsian kritik sastra tersebut penting diimplementasikan ancangan literasi kritis dalam menulis resensi.

Literasi adalah kemahiran membaca dan menulis. Literasi kritis dapat dimaknai sebagai kemahiran membaca dan menulis secara kritis. Seiring berkembangnya ilmu pengetahuan, literasi memiliki banyak pengertian. Priyatni (2012:27) mengemukakan bahwa istilah literasi kritis berkaitan dengan berpikir kritis dan kesadaran kritis. Berpikir kritis adalah kemampuan untuk berpikir logis dengan cara bertanya, menganalisis, membandingkan, mengontraskan, dan mengevaluasi. Kesadaran kritis adalah kemampuan mengenali kondisi yang menghasilkan ide-ide istimewa dalam suatu budaya atau masyarakat tertentu. Dengan demikian, resensi hendaknya meningkatkan kepekaannya terhadap faktafakta sosial yang diungkapkan oleh penulis melalui karya-karyanya secara implisit untuk memberikan informasi kepada pembaca secara utuh (lengkap) tentang karya sastra yang diresensi. Kesimpulan tersebut sekaligus memberikan pertimbangan bahwa konsep literasi kritis cocok diterapkan dalam langkah-langkah pembelajaran menulis resensi.

Berdasarkan hasil studi, pembelajaran menulis di kelas belum mencapai level kritis untuk mengkaji karya sastra. Pembelajaran yang demikian menunjukkan ketidaksesuaian proses belajar yang disajikan dengan level berpikir yang seharusnya dikuasai siswa. Seperti yang disampaikan oleh Crain (2007:202) bahwa menurut teori perkembangan kognitif Piaget, anak usia 11 tahun-dewasa berada pada tahap operasi formal dimana pikiran mencapai derajat kesetimbangan tertinggi terkait dengan hipotesis yang diajukan. Dalam kondisi semacam ini, keberadaan bahan ajar sebagai pendukung pembelajaran menjadi penting, khususnya bahan ajar yang memiliki inovasi baru untuk mengembangkan daya nalar peserta didik. Untuk mendukung pengembangan daya nalar peserta didik tersebut, konsep literasi kritis digunakan sebagai pijakan dalam menyusun langkah-langkah pembelajaran menulis resensi sebagai bentuk inovasi baru dari bahan ajar yang dikembangkan. Selain mementingkan kebaruan bahan ajar yang sesuai dengan level berpikir siswa, implementasi konsep literasi kritis dalam bahan ajar pembelajaran menulis resensi diharapkan dapat memandu siswa untuk 
berpikir kritis dan memiliki kesadaran kritis dalam mengkaji karya sastra yang kemudian dituangkan dalam tulisan berupa resensi.

Salah satu bagian penting dalam penyusunan bahan ajar adalah uji kelayakan. Suatu bahan ajar tidak dapat digunakan dan berfungsi dengan baik tanpa uji kelayakan untuk mengetahui layak atau tidaknya suatu bahan ajar sebagai pendukung pembelajaran. Menurut Badan Standar Nasional Pendidikan (2006), buku sebagai bahan ajar berkualitas wajib memenuhi empat unsur kelayakan, yaitu kelayakan isi, kelayakan penyajian, kelayakan kebahasaan, dan kelayakan kegrafikan. Berdasarkan empat kriteria kelayakan buku ajar menurut BSNP tersebut, Syamsul \& Kusrianto (2009:104 - 121) dan Muslich (2010:292 — 313) menjabarkan parameter kelayakan buku ajar seperti berikut ini. Pertama, penilaian kelayakan isi, meliputi (1) kesesuaian uraian materi dengan SK dan KD, (2) cakupan materi, (3) keakuratan materi, (4) kemutakhiran materi, (5) materi pendukung pembelajaran, (6) menumbuhkan semangat produktivitas, (7) memotivasi keingintahuan, (8) mengembangkan sikap hidup (life skills), dan (9) mengembangkan sikap menghargai. Kedua, penilaian kelayakan penyajian, meliputi (1) teknik penyajian berkenaan dengan sistematika, (2) penyajian pembelajaran, dan (3) kelengkapan penyajian. Ketiga, Penilaian kelayakan bahasa, yaitu (1) kesesuaian bahasa dengan tingkat perkembangan siswa, (2) kekomunikatifan, dan (3) keruntutan dan keterpaduan alur pikir. Keempat, penilaian kelayakan kegrafikan, meliputi (1) ukuran buku, (2) desain kulit buku, (3) desain isi buku, termasuk keterbacaan di dalamnya.

Penelitian ini tidak lepas dari penelitian terdahulu yang relevan, yaitu penelitian yang dilakukan oleh Bernadus Gae Longa (2014) dengan judul Pengembangan Bahan Ajar Membaca Cerpen dengan Ancangan Literasi Kritis. Hasil dari penelitian tersebut menunjukkan bahwa bahan ajar yang dikembangkan layak untuk digunakan dalam pembelajaan membaca cerpen.Bahan ajar berupa buku yang dikembangkan tersebut berupa buku pengayaan, yaitu buku yang memuat materi yang dapat memperkaya buku teks wajib untuk pendidikan menengah (Sitepu, 2012:17). Berdasarkan penelitian tersebut, dapat diketahui 
bahwa keterampilan membaca dengan pendekatan proses memperoleh hasil yang bagus sehingga buku yang dikembangkan layak untuk diterapkan.

Berdasarkan latar belakang tersebut, tujuan penelitian ini adalah untuk menghasilkan bahan ajar menulis resensi cerpen berbasis literasi kritis bagi siswa SMA kelas XI yang memenuhi kelayakan isi, penyajian materi, bahasa dan keterbacaan, kegrafikaan, daya terap dan serap materi literasi kritis, kebermanfaatan dan kemenarikan, serta untuk mengetahui tingkat keefektifan bahan ajar dalam pembelajaran menulis resensi kritis cerpen.

\section{METODE}

Prosedur penelitian pengembangan ini terdiri atas delapan tahapan yang merupakan adaptasi dari model penelitian dan pengembangan Borg \& Gall. Kedelapan tahapan tersebut, meliputi (1) observasi dan pengumpulan informasi, (2) perencanaan, (3) pengembangan draf produk, (4) uji kelayakan, (5) revisi, (6) uji lapangan, (7) penyempurnaan produk akhir, dan (8) uji keefektifan produk. Setelah produk dinyatakan layak diimplementasikan, dilakukan uji keefektifan produk untuk mengetahui keefektifan produk dalam pembelajaran menulis resensi kritis cerpen. Uji keefektifan produk dilakukan dengan desain praeksperimen, yaitu pretes-postes kelompok tunggal.

Data yang didapatkan pada penelitian ini berupa data kuantitatif dan kualitatif. Data kuantitatif diperoleh dari skor penilaian yang diberikan oleh dua ahli, tiga guru, dan 30 siswa, serta skor pretes dan postes pada uji keefektifan. Data kualitatif diperoleh dari komentar dan saran yang diberikan oleh ahli, guru, dan siswa. Data kuantitatif dianalisis dengan teknik statistik deskriptif. Selanjutnya, uji keefektifan produk dilakukan dengan uji eksperimen. Desain eksperimen yang digunakan adalah desain praeksperimen (pre-experimental design), yaitu pretes-postes kelompok tunggal (one-group pretest-posttest design) (Sugiyono, 2013:109-110).Analisis data yang digunakan untuk mengetahui keefektifan produk tersebut berupa rumus uji-t dengan bantuan program SPSS 20.0 for Windows. 


\section{HASIL DAN PEMBAHASAN}

Produk yang dikembangkan pada penelitian ini berupa bahan ajar Menulis Resensi Cerpen Berbasis Literasi Kritis bagi Siswa SMA Kelas XI. Bahan ajar ini merupakan bahan pengayaan sebagai pendamping bahan ajar wajib bagi siswa. Pendekatan literasi kritis yang diterapkan dalam langkah-langkah pembelajaran menulis resensi pada bahan ajar ini berfungsi memunculkan pemikiran kritis dan kesadaran kritis siswa untuk menemukan praktik-praktik sosial dalam cerpen. Oleh sebab itu, cerpen-cerpen yang disajikan dalam bahan ajar ini dipilih cerpen yang memuat praktik sosial karena adanya kekuasaan pihak tertentu.

Bahan ajar menulis resensi cerpen berbasis literasi kritis dikemas dalam bentuk buku siswa. Buku siswa ini dicetak pada bidang kertas B5 yang berukuran $182 \times 257 \mathrm{~mm}$. Proporsi margin buku mencakup margin kiri 2,54 cm, margin atas $2,54 \mathrm{~cm}$, margin kanan $2 \mathrm{~cm}$, dan margin bawah $2 \mathrm{~cm}$. Isi buku siswa ini ditulis menggunakan empat jenis font, yaitu (1) Cambria cetak tebal berukuran $12 \mathrm{pt}$ dengan spasi 1,5 untuk penulisan subbab dan sub dari subbab, (2) Century Schoolbook berukuran 11 pt dengan spasi 1,5 untuk uraian materi dan latihan, (3) Maiandra GD berukuran 9 pt dengan spasi 1 untuk cerpen, berukuran $10 \mathrm{pt}$ dengan spasi 1 untuk contoh resensi dan kutipan cerpen pada latihan, serta (4) Calibri (Body) berukuran 11 pt dengan spasi 1 untuk kutipan teks pada penjelasan materi.

Bahan ajar ini dikembangkan dari Kompetensi Dasar SMA Kurikulum 2013 terbaru yang telah disahkan oleh Pusat Kurikulum dan Perbukuan pada tahun 2016, yaitu KD 4.15 Menulis resensi karya (buku fiksi, nonfiksi, komik, film, atau pertunjukan) dengan memerhatikan isi dan kebahasaan. Berdasarkan KD tersebut, bagian isi bahan ajar Menulis Resensi Cerpen Berbasis Literasi Kritis bagi Siswa SMA Kelas XI dikembangkan menjadi lima bab, meliputi (1) Bab 1 Konsep Menulis Resensi Kritis, (2) Bab 2 Menulis Pendahuluan Resensi Kritis, (3) Menulis Isi Resensi Kritis, (4) Menulis Penutup Resensi Kritis, dan (5) Praktik Menulis Resensi Kritis.

Setiap bab dalam bahan ajar ini diawali dengan paparan materi pokok yang diperlukan siswa tentang topik yang akan dipelajari dalam bab tersebut. Setelah 
itu, disajikan contoh-contoh yang mempermudah siswa untuk memahami materi sekaligus sebagai model penerapan materi tersebut. Selanjutnya, siswa diberikan latihan-latihan sebagai wahana praktik bagi siswa untuk menerapkan pemahaman materi yang telah dicapai. Dengan struktur yang sistematis dan komposisi materi memadai, bahan ajar ini dapat membimbing siswa untuk menghasilkan resensi kritis.

Produk yang dihasilkan dalam penelitian dan pengembangan ini berupa buku pengayaan bagi siswa untuk menulis resensi cerpen secara kritis yang berjudul Terampil Menulis Resensi Sastra berbasis Literasi Kritis bagi Siswa SMA Kelas XI. Pada judul tersebut dipilih kosakata "resensi sastra", bukan "resensi cerpen" karena pada hakikatnya bahan ajar yang dihasilkan ini dapat digunakan sebagai pegangan untuk penulisan resensi sastra selain cerpen. Penentuan bahan ajar sebagai buku pengayaan tersebut sesuai dengan pendapat Prastowo (2012:168) bahwa buku pelengkap atau pengayaan adalah buku yang sifatnya membantu atau merupakan tambahan bagi buku teks utama serta digunakan oleh pendidik dan peserta didik.

Pemanfaatan pendekatan literasi kritis dalam bahan ajar menulis resensi kritis ini digunakan sebagai alat untuk mengupas muatan praktik sosial yang terdapat dalam cerpen yang dibaca. Muatan praktik sosial yang dimaksud ialah praktik sosial yang muncul akibat adanya pihak yang berkuasa dan dikuasai. Seperti yang disampaikan oleh Hood (1998:11) bahwa literasi kritis dalam ranah bahasa dan pendidikan memandang wacana sebagai konstruk sosial, yang merefleksikan dan membantu membangun hubungan kekuasaan melalui penyelidikan dan pemberian hak istimewa posisi ideologis tertentu.

\section{Hasil Validasi Uji Produk}

Bahan ajar yang dikembangkan ini diuji melalui dua tahap uji agar diperoleh data yang valid mengenai kelayakan bahan ajar menulis resensi cerpen berbasis literasi kritis. Dua tahap tersebut, yaitu validasi kelayakan oleh ahli dan praktisi serta kelayakan saat uji lapangan terbatas. Pada subbab ini akan diuraikan hasil validasi dan uji produk, meliputi (1) kelayakan isi bahan ajar, (2) kelayakan penyajian materi bahan ajar, (3) kelayakan bahasa dan keterbacaan bahan ajar, (4) 
kelayakan kegrafikaan bahan ajar, (5) kelayakan daya terap materi literasi kritis, (6) kelayakan daya serap materi literasi kritis, serta (7) kelayakan kebermanfaatan dan kemenarikan bahan ajar.

1. kelayakan isi bahan ajar. Kelayakan isi bahan ajar menulis resensi cerpen berbasis literasi kritis terdiri atas tiga aspek. Ketiga aspek tersebut meliputi (1) kesesuaian materi dengan kurikulum, (2) keakuratan materi, dan (3) materi pendukung pembelajaran. Penilaian terhadap ketiga aspek tersebut diperoleh dari ahli pembelajaran sastra dan ahli bahan ajar. Aspek kesesuaian materi dengan kurikulum memperoleh persentase rata-rata kelayakan sebesar $80 \%$ sehingga layak diimplementasikan. Aspek keakuratan materi memperoleh rata-rata persentase $70 \%$ sehingga layak diimplementasikan. Aspek materi pendukung pembelajaran memperoleh persentase skor rata-rata sebesar $76,67 \%$ sehingga layak diimplementasikan.

Kajian produk berdasarkan isi bahan ajar meliputi (1) kesesuaian materi dengan kurikulum, (2) keakuratan materi, dan (3) materi pendukung pembelajaran. Pertama, aspek kesesuaian materi dengan kurikulum mencapai persentase $80 \%$ sehingga termasuk dalam kategori layak. Isi bahan ajar dipandang dari aspek kesesuaian materi dengan kurikulum dinyatakan layak untuk diimplementasikan karena telah memenuhi tiga kriteria, yaitu (1) materi resensi yang disajikan dalam buku sesuai dengan KI dan KD yang berlaku, (2) materi tentang konsep literasi kritis dan menulis resensi dipaparkan secara mendalam, dan (3) materi tentang konsep literasi kritis dan menulis resensi disajikan secara padu dari awal hingga akhir. Berdasarkan revisi yang telah dilakukan sesuai dengan komentar dan saran dari ahli pembelajaran sastra dan ahli bahan ajar sebagai penilai kelayakan aspek tersebut, bahan ajar menulis resensi cerpen berbasis literasi kritis yang dihasilkan layak diimplementasikan.

Kedua, aspek keakuratan materi memperoleh persentase sebesar 70\% sehingga termasuk dalam kategori layak. Isi bahan ajar dipandang dari aspek keakuratan materi dinyatakan layak untuk diimplementasikan karena telah memenuhi tiga kriteria, yaitu (1) konsep materi literasi kritis dan materi menulis resensi kritis akurat, (2) cerpen yang disajikan sebagai contoh dan 
bahan latihan memenuhi syarat untuk dikupas muatan praktik sosialnya, dan (3) contoh resensi yang disajikan dalam buku memenuhi syarat sebagai resensi kritis yang menerapkan pendekatan literasi kritis. Berdasarkan revisi yang telah dilakukan sesuai dengan komentar dan saran dari ahli pembelajaran sastra dan ahli bahan ajar sebagai penilai kelayakan aspek tersebut, bahan ajar menulis resensi cerpen berbasis literasi kritis yang dihasilkan layak diimplementasikan.

Ketiga, aspek materi pendukung pembelajaran memperoleh persentase $76,67 \%$ sehingga termasuk dalam kategori layak. Isi bahan ajar dipandang dari aspek materi pendukung pembelajaran dinyatakan layak untuk diimplementasikan karena telah memenuhi tiga kriteria, yaitu (1) materi mampu menumbuhkan kemampuan berpikir kritis peserta didik, (2) materi mampu memudahkan peserta didik untuk menulis resensi kritis secara runtut dengan memerhatikan kualitas isi dan bahasa, dan (3) materi mampu memunculkan kesadaran kritis siswa untuk memahami makna tersirat dari teks terkait dengan ideologi yang ada di balik teks. Berdasarkan revisi yang telah dilakukan sesuai dengan komentar dan saran dari ahli pembelajaran sastra dan ahli bahan ajar sebagai penilai kelayakan aspek tersebut, bahan ajar menulis resensi cerpen berbasis literasi kritis yang dihasilkan layak diimplementasikan.

2. Kelayakan penyajian materi bahan ajar. Fokus pembahasan untuk menentukan tingkat kelayakan penyajian materi bahan ajar terdiri atas tiga aspek, yaitu (1) teknik penyajian materi, (2) penyajian pembelajaran, dan (3) kelengkapan penyajian bahan ajar. Dalam penelitian ini, data untuk mengetahui kelayakan teknik penyajian materi diperoleh dari penilaian ahli. Data untuk mengetahui kelayakan penyajian pembelajaran diperoleh dari penilaian ahli dan praktisi. Sementara itu, data untuk mengetahui kelayakan kelengkapan penyajian bahan ajar diperoleh dari penilaian ahli dan respon siswa.Aspek teknik penyajian bahan ajar memperoleh rata-rata persentase skor sebesar 92\% sehingga sangat layak diimplementasikan. Selanjutnya, pada aspek penyajian pembelajaran diperoleh persentase rata-rata skor sebesar 78,09\% sehingga layak diimplementasikan. Berdasarkan penilaian oleh ahli dan mempertimbangkan 
respon dari siswa, aspek kelengkapan bahan ajar pada produk dipandang sangat lengkap. Hal tersebut dapat diketahui dari perolehan persentase ratarata skor sebesar $83,80 \%$ sehingga sangat layak diimplementasikan.

Kajian produk berdasarkan penyajian materi bahan ajar meliputi (1) teknik penyajian materi, (2) penyajian pembelajaran, dan (3) kelengkapan penyajian bahan ajar. Pertama, aspek teknik penyajian bahan ajar memperoleh rata-rata persentase skor sebesar 92\% sehingga termasuk dalam kategori sangat layak. Penyajian materi bahan ajar dipandang dari teknik penyajian materi dinyatakan layak untuk diimplementasikan apabila memenuhi lima kriteria, yaitu (1) tujuan pembelajaran disampaikan secara eksplisit dan jelas, (2) materi menulis resensi kritis disajikan secara runtut dan sesuai dengan konsep literasi kritis, (3) bab-bab dalam buku disajikan secara runtut sesuai dengan kesinambungan materi berupa proses untuk menghasilkan resensi kritis cerpen, (4) penyusunan materi dalam setiap bab konsisten sesuai dengan porsi kebutuhan masing-masing, dan (5) bab-bab dalam buku disajikan dengan proporsi seimbang. Berdasarkan revisi yang telah dilakukan sesuai dengan komentar dan saran dari ahli pembelajaran sastra dan ahli bahan ajar sebagai penilai kelayakan aspek tersebut, bahan ajar menulis resensi cerpen berbasis literasi kritis yang dihasilkan layak diimplementasikan karena telah memenuhi kelima kriteria tersebut.

Kedua, aspek penyajian pembelajaran memperoleh rata-rata persentase skor sebesar 78,09\% sehingga termasuk dalam kategori layak. Penyajian materi bahan ajar dipandang dari aspek penyajian pembelajaran dinyatakan layak untuk diimplementasikan apabila memenuhi delapan kriteria, yaitu (1) indikator pembelajaran menjadi acuan pencapaian kemampuan siswa dalam menulis resensi berbasis literasi kritis, (2) penyajian materi dan proses pembelajaran berpusat pada peserta didik untuk menumbuhkan pemikiran kritis dengan literasi kritis dalam menulis resensi, (3) penyajian kegiatan pembelajaran mendorong peserta didik untuk mengembangkan keterampilan proses, dalam hal ini proses menulis resensi kritis, (4) penyajian pembelajaran memerhatikan aspek bahasa yang baik dan benar, (5) materi tahap-tahap 
menulis resensi berbasis literasi kritis yang disajikan mudah dipahami oleh siswa, (6) kegiatan pembelajaran yang disajikan mampu mendorong peserta didik untuk berpikir kritis dan memiliki kesadaran kritis untuk mengulas cerpen, (7) penyajian kegiatan pembelajaran mampu menuntun peserta didik untuk menggali informasi terkait dengan pemahaman lebih dalam terhadap cerpen yang diresensi, (8) penyajian contoh resensi kritis memperjelas pemahaman peserta didik terkait dengan penerapan literasi kritis untuk menggali bentuk kekuasaan yang ada di balik teks. Berdasarkan revisi yang telah dilakukan sesuai dengan komentar dan saran dari ahli pembelajaran sastra, ahli bahan ajar, dan praktisi sebagai penilai kelayakan aspek tersebut, bahan ajar menulis resensi cerpen berbasis literasi kritis yang dihasilkan layak diimplementasikan karena telah memenuhi delapan kriteria di atas.

Ketiga, aspek kelengkapan bahan ajar memperoleh persentase sebesar $83,80 \%$ sehingga termasuk dalam kategori sangat layak. Penyajian materi bahan ajar dipandang dari aspek kelengkapan bahan ajar dinyatakan layak untuk diimplementasikan apabila memenuhi enam kriteria, yaitu (1) petunjuk penggunaan buku siswa dapat menuntun siswa menggunakan ancangan literasi kritis untuk menulis resensi kritis, (2) penyajian kata pengantar di bagian awal buku tepat, (3) penyajian peta konsep kegiatan pembelajaran pada tiap-tiap bab jelas, (4) penyajian daftar isi jelas dan tepat, (5) penyajian daftar pustaka tepat, dan (6) pengaturan proporsi materi, contoh, dan evaluasi tepat. Berdasarkan revisi yang telah dilakukan sesuai dengan komentar dan saran dari ahli pembelajaran sastra dan ahli bahan ajar sebagai penilai kelayakan aspek tersebut serta memerhatikan respon dari siswa, bahan ajar menulis resensi cerpen berbasis literasi kritis yang dihasilkan layak diimplementasikan karena telah memenuhi enam kriteria tersebut.

3. Kelayakan bahasa dan keterbacaan bahan ajar. Kelayakan bahasa dan keterbacaan bahan ajar menulis resensi cerpen berbasis literasi kritis memperoleh rata-rata skor penilaian dengan persentase sebesar $84,18 \%$ sehingga sangat layak diimplementasikan. 
Kajian bahasa dan keterbacaan bahan ajar fokus pada beberapa hal, yaitu ketepatan struktur kalimat, keefektifan kalimat, ketepatan penggunaan istilah baku, penyajian dengan bahasa yang komunikatif dan persuasif, kesesuaian wacana dengan konteks pembelajaran, serta kesesuaian struktur kebahasaan dan kesastraan dengan perkembangan kognitif siswa. Hal tersebut sesuai dengan tujuh landasan keterbacaan materi dan bahasa dalam penulisan buku teks menurut Muslich (2010:170), yaitu (1) komunikatif, (2) dialogis dan interaktif, (3) lugas, (4) keruntutan alur pikir, (5) koherensi, (6) kesesuaian dengan kaidah bahasa, dan (7) penggunaan istilah dan simbol yang sesuai dengan perkembangan peserta didik.

Berdasarkan penilaian oleh ahli pembelajaran sastra, ahli bahan ajar, dan praktisi, bahan ajar menulis resensi cerpen berbasis literasi kritis yang dikembangkan ini perlu dilakukan revisi pada poin kesesuaian struktur kebahasaan dan kesastraan dengan perkembangan kognitif siswa. Melalui data numerik, bahasa dan keterbacaan bahan ajar memperoleh persentase $84,18 \%$ sehingga sangat layak diimplementasikan. Berdasarkan perolehan persentase dan perbaikan yang telah dilakukan sesuai dengan saran yang diberikan, bahan ajar menulis resensi cerpen berbasis literasi kritis yang dihasilkan layak diimplementasikan.

4. Kelayakan kegrafikaan bahan ajar. Aspek kegrafikaan bahan ajar menulis resensi cerpen berbasis literasi kritis memperoleh persentase rata-rata skor sebesar $94,20 \%$.

Aspek kegrafikaan bahan ajar menulis resensi cerpen berbasis literasi kritis memperoleh persentase sebesar 94,20\% yang termasuk dalam kategori sangat layak. Kajian terhadap kegrafikaan bahan ajar fokus pada tampilan bahan ajar. Aspek kegrafikaan bahan ajar dapat dipandang layak diimplementasikan apabila memenuhi kualifikasi "baik" terkait dengan beberapa hal, meliputi (1) kesesuaian ukuran format buku dengan aturan pengembangan produk dan kemenarikan produk, (2) kemenarikan desain sampul luar/kulit dan kesesuaiannya dengan isi buku, (3) kemenarikan desain sampul dalam/tiap judul bab dan kesesuaiannya dengan isi bab, (4) 
kemenarikan desain isi buku bagi siswa SMA berkenaan dengan tampilan komposisi bentuk dan warna, (5) kesesuaian font dengan perkembangan peserta didik, (6) ketepatan tata letak (layout) buku, (7) kualitas kertas yang digunakan bagus, dan (8) kualitas cetakan dan penjilidan bagus. Melalui penelitian yang dilakukan, diperoleh komentar dari ahli bahan ajar bahwa variasi font perlu ditambah. Berdasarkan revisi yang telah dilakukan sesuai dengan komentar dan saran dari ahli bahan ajar tersebut, bahan ajar menulis resensi cerpen berbasis literasi kritis yang dihasilkan layak diimplementasikan.

5. Kelayakan daya terap materi literasi kritis. Aspek daya terap materi literasi kritis dalam bahan ajar yang dikembangkan ini diuji kelayakannya oleh praktisi sebagai pelaksana pembelajaran di kelas. Berdasarkan penilaian yang diberikan oleh ketiga praktisi, daya terap materi literasi kritis dalam bahan ajar ini memperoleh persentase rata-rata skor sebesar $81,36 \%$.

6. Kelayakan daya serap materi literasi kritis. Aspek kelayakan daya serap materi literasi kritis bahan ajar menulis resensi cerpen berbasis literasi kritis memperoleh persentase rata-rata skor sebesar $77,40 \%$ sehingga layak diimplementasikan pada pembelajaran menulis resensi cerpen.

Berdasarkan penilaian yang diberikan oleh praktisi, daya terap materi literasi kritis dalam bahan ajar ini memperoleh persentase sebesar 81,36\% yang masuk pada kategori sangat layak. Berdasarkan analisis data yang dilakukan, bahan ajar ini memenuhi kelayakan daya terap materi literasi kritis karena telah memenuhi beberapa indikator, yaitu (1) petunjuk penggunaan buku siswa mampu menuntun siswa untuk menggunakan pendekatan literasi kritis dalam menulis resensi, (2) indikator pembelajaran menjadi acuan pencapaian kemampuan siswa dalam menulis resensi berbasis literasi kritis, (3) konsep materi literasi kritis memungkinkan pengembangan kemampuan berpikir kritis dan kesadaran kritis siswa dalam mengulas cerpen, (4) kegiatan menulis resensi cerpen mengacu pada penerapan pendekatan literasi kritis dalam pembelajaran, dan (5) penerapan pendekatan literasi kritis dalam menulis resensi cerpen dikembangkan berdasarkan bagian-bagian resensi sesuai dengan tahapan menulis resensi. Dengan demikian, dipandang dari 
aspek daya terap materi literasi kritis, bahan ajar menulis resensi cerpen berbasis literasi kritis yang dikembangkan layak diimplementasikan pada pembelajaran menulis resensi kritis cerpen.

Daya serap materi literasi kritis didasarkan pada kemampuan siswa dalam memahami teori dan keterampilan dalam praktik menulis resensi kritis dengan menggunakan bahan ajar yang dikembangkan ini. Tingkat daya serap materi literasi tersebut ditandai dengan tujuh indikator, yaitu (1) langkahlangkah pembelajaan memudahkan siswa untuk memahami materi menulis resensi cerpen secara kritis, (2) siswa dapat memahami unsur-unsur resensi kritis dengan buku yang dikembangkan, (3) contoh-contoh yang disajikan memudahkan siswa dalam memahami materi, (4) kegiatan latihan menulis resensi cerpen berbasis literasi kritis dapat siswa lakukan dengan baik, (5) siswa mampu mengulas isi cerpen dengan menerapkan literasi kritis menggunakan buku yang dikembangkan, (6) langkah-langkah pembelajaran menulis resensi cerpen berbasis literasi kritis dapat siswa ikuti dengan baik, dan (7) latihan-latihan yang ada dalam bahan ajar mampu membuat siswa lebih memahami tahap-tahap menulis resensi dengan pendekatan literasi kritis. Berdasarkan indikator tersebut, melalui respon siswa diketahui bahwa daya serap materi literasi kritis bahan ajar menulis resensi cerpen berbasis literasi kritis memperoleh persentase sebesar $77,40 \%$ sehingga layak diimplementasikan pada pembelajaran menulis resensi cerpen.

7. Kelayakan kebermanfaatan dan kemenarikan bahan ajar. Aspek kelayakan kebermanfaatan dan kemenarikan bahan ajar menulis resensi kritis diketahui berdasarkan penilaian dari praktisi dan respon siswa. Hasil penilaian praktisi dan respon siswa tersebut menunjukkan bahwa pada aspek kelayakan daya tarik dan daya manfaat bahan ajar menulis resensi cerpen berbasis literasi kritis ini diperoleh persentase rata-rata skor sebesar 79,96\%.

Kajian terkait dengan kebermanfaatan dan kemenarikan bahan ajar ini dilakukan berdasarkan penilaian praktisi dan siswa yang akan menjadi pengguna langsung bahan ajar menulis resensi cerpen berbasis literasi kritis. Penilaian daya tarik bahan ajar oleh praktisi fokus pada kebermanfaatan bahan 
ajar bagi siswa dan tampilan bahan ajar. Dikatakan memiliki daya tarik oleh praktisi apabila bahan ajar menulis resensi kritis cerpen memenuhi beberapa kriteria, yaitu (1) dapat menunjang kebutuhan siswa SMA sebagai bahan pengayaan, (2) materi literasi kritis dalam bahan ajar mampu menumbuhkan kemampuan berpikir kritis dan kesadaran kritis siswa SMA, (3) bahan ajar mampu memudahkan siswa untuk menulis resensi kritis, (4) desain sampul luar/kulit menarik dan sesuai dengan isi buku, (5) desain sampul dalam/tiap judul bab menarik dan sesuai dengan isi bab, (6) desain isi buku menarik bagi siswa SMA berkenaan dengan tampilan komposisi bentuk dan warna, serta (7) kualitas cetakan dan penjilidan buku bagus.

Sementara itu, kajian kebermanfaatan dan kemenarikan bahan ajar berdasarkan penilaian siswa terkait dengan manfaatnya bagi diri siswa, kemudahan untuk dipelajari, dan motivasi siswa untuk mempelajari bahan ajar tersebut. Kebermanfaatan dan kemenarikan bahan ajar berdasarkan penilaian siswa tersebut didasarkan pada beberapa kriteria, yaitu (1) pembelajaran menulis resensi kritis dengan buku ini menyenangkan dan bermanfaat bagi siswa, (2) setelah mengerjakan semua kegiatan dalam buku ini siswa merasa lebih percaya dirijika sewaktu-waktu diminta menulis resensi kritis, (3) bahan ajar ini mampu menumbuhkan pemikiran kritis siswa dalam mengulas cerpen, (4) kegiatan pembelajaran menulis resensi cerpen berbasis literasi kritis ini dapat memotivasi siswa untuk belajar? (5) buku ini bermanfaat untuk meningkatkan keterampilan siswa dalam menulis resensi kritis, (6) siswa tertarik dengan desain dan warna yang disajikan pada buku ini, (7) huruf-huruf pada buku ini dapat dibaca dengan nyaman, (8) bahasa yang digunakan mudah dipahami dan komunikatif, (9) secara keseluruhan buku ini memotivasi siswa untuk belajar.

Hasil penilaian praktisi dan respon siswa menunjukkan bahwa pada aspek kebermanfaatan dan kemenarikan bahan ajar menulis resensi cerpen berbasis literasi kritis ini diperoleh persentase sebesar 79,96\% yang masuk pada kategori layak. Dengan demikian, bahan ajar yang dikembangkan ini layak diimplementasikan karena menarik dan bermanfaat bagi guru dan siswa. 


\section{Efektivitas Bahan Ajar}

Uji keefektifan bahan ajar dilakukan untuk mengetahui kemampuan bahan ajar menulis resensi cerpen berbasis literasi kritis dalam meningkatkan keterampilan menulis resensi kritis siswa. Kegiatan eksperimen untuk menguji keefektifan produk dilakukan dengan tiga tahap, yaitu pretes, memberi perlakuan dengan menggunakan bahan ajar menulis resensi cerpen berbasis literasi kritis, dan postes. Berdasarkan hasil uji eksperimen pada 30 siswa kelas SMA Negeri 1 Wates, Kulon Progo, Yogyakarta yang dianalisis dengan uji-t sampel berpasangan, diketahui bahwa terdapat perbedaan yang signifikan antara skor kemampuan menulis resensi kritis cerpen sebelum dan setelah pemberian perlakuan. Dengan demikian, bahan ajar yang dikembangkan efektif digunakan dalam pembelajaran menulis resensi kritis. Berikut ini hasil perhitungan statistika keefektifan bahan ajar.

Tabel 1 Hasil Statistik Uji Beda Sampel Berpasangan terhadap

Keterampilan Menulis Resensi Kritis Cerpen

\begin{tabular}{|c|c|c|c|c|c|}
\hline \multicolumn{5}{|c|}{ Paired Samples Statistics } \\
\hline \multicolumn{2}{|c|}{} & Mean & N & Std. Deviation & $\begin{array}{c}\text { Std. Error } \\
\text { Mean }\end{array}$ \\
\hline Pair 1 & Pretest & 77,03 & 30 & 6,128 & 1,119 \\
\cline { 2 - 6 } & Posttest & 88,83 & 30 & 6,613 & 1,207 \\
\hline
\end{tabular}

\begin{tabular}{|c|c|c|c|c|c|c|c|c|c|}
\hline \multicolumn{10}{|c|}{ Paired Samples Test } \\
\hline & & \multicolumn{5}{|c|}{ Paired Differences } & \multirow[b]{3}{*}{$\mathrm{T}$} & \multirow[b]{3}{*}{ df } & \multirow{3}{*}{$\begin{array}{l}\text { Sig. } \\
(2- \\
\text { tailed) }\end{array}$} \\
\hline & & \multirow[b]{2}{*}{ Mean } & \multirow{2}{*}{$\begin{array}{c}\text { Std. } \\
\text { Deviation }\end{array}$} & \multirow{2}{*}{$\begin{array}{l}\text { Std. } \\
\text { Error } \\
\text { Mean }\end{array}$} & \multicolumn{2}{|c|}{$\begin{array}{l}95 \% \text { Confidence } \\
\text { Interval of the } \\
\text { Difference }\end{array}$} & & & \\
\hline & & & & & Lower & Upper & & & \\
\hline Pair 1 & $\begin{array}{l}\text { Pretest - } \\
\text { Posttest }\end{array}$ & $-11,800$ & 1,540 &, 281 & $-12,375$ & $-11,225$ & $-41,961$ & 29 &, 000 \\
\hline
\end{tabular}

Dari hasil statistik uji beda kemampuan menulis resensi kritis cerpen sebelum dan setelah perlakuan diketahui $\mathrm{t}=-41,961$ dan $\mathrm{p}=0,000$. Dengan demikian, terdapat perbedaan signifikan antara skor kemampuan menulis resensi kritis cerpen sebelum dan setelah pemberian perlakuan karena $\mathrm{p}<\alpha 0,05$.

Hasil analisis tersebut menunjukkan bahwa skor pretes dan postes berbeda secara signifikan. Perbedaan tersebut terjadi karena adanya perlakuan, yaitu 
dilaksanaknnya pembelajaran menulis resensi kritis cerpen menggunakan bahan ajar menulis resensi cerpen berbasis literasi kritis. Dengan adanya perlakuan, skor kemampuan menulis resensi kritis setelah perlakuan menjadi lebih tinggi dibandingkan dengan skor sebelum perlakuan.

\section{SIMPULAN}

Berdasarkan hasil validasi, uji produk, dan penghitungan secara statistik, dapat disimpulkan bahwa bahan ajar menulis resensi cerpen berbasis literasi kritis efektif dan layak diimplementasikan dalam pembelajaran menulis resensi kritis cerpen. Dengan demikian, bahan ajar menulis resensi cerpen berbasis literasi kritis dapat dijadikan sebagai salah satu alternatif bahan ajar pengayaan bagi siswa SMA kelas XI dalam menulis resensi untuk menghasilkan resensi kritis.

Bahan ajar yang dihasilkan dalam penelitian dan pengembangan ini hanya terkait dengan satu keterampilan, yakni menulis. Oleh sebab itu, diperlukan penelitian lanjutan yang menghasilkan produk untuk keterampilan yang lain. Selain itu, bahan ajar yang telah dihasilkan ini dapat diperluas jangkauannya untuk menulis resensi sastra yang lain, seperti resensi novel, film, drama, dan puisi.

\section{DAFTAR PUSTAKA}

Applebee, A.N. 2000. Alternative Models of Writing Development. Dalam Roselmina Indrisano dan James R. Squire (Ed.), Perspective on Writing. Research, Theory, and Practice(hlm. 90-109). Canada: International Reading Association.

Arifin, S. \& Kusrianto, A. 2009. Sukses Menulis Buku Ajar \& Referensi. Jakarta: Grasindo.

Asia and The Pacific Programme of Educatioal Innovation for Development (APEID). 1985. Textbooks and Related Teaching/Learning Materials. Bangkok: Unesco Regional Office for Education in Asia and the Pacific.

Badan Standar Nasional Pendidikan (BSNP). 2006. Panduan Penyusunan Kurikulum Tingkat Satuan Pendidikan Jenjang Pendidikan Dasar dan Menengah. Jakarta: BSNP. 
Borg, W.R. \& Gall, M.D. 1983. Educational Research An Introduction. Fourth Edition. New York\&London: Longman.

Burden, P.R. \& Byrd, D.M. 2013. Methods for Effective Teaching. Sixth Edition. Boston: Pearson.

Crain, W. 2007. Teori Perkembangan: Konsep dan Aplikasi. Edisi Ketiga. Yogyakarta: Pustaka Pelajar.

Cunningsworth, A. 1995. Choosing Your Coursbook. Oxford: Heineman.

Depdiknas. 2006. Pedoman Penilaian Buku Teks Pelajaran Bahasa dan Sastra Indonesia untuk SMP/MTs dan SMA/MA. Jakarta: Pusat Perbukuan Depdiknas.

Ghazali, A.S. 2013. Pembelajaran Keterampilan Berbahasa dengan Pendekatan Komunikatif-Interaktif. Bandung: Refika Aditama.

Hood, S. 1998. Critical Literacy: What Does it Mean in Theory and Practice? Dalam Anne Burns \& Susan Hood (Ed.), Teachers' Voices 3: Teaching Critical Literacy (hlm. 11-19). Sydney: National Centre for English Language Teaching and Research Macquarie University.

Kuncoro, M. 2009. Mahir Menulis: Kiat Jitu Menulis Artikel Opini, Kolom, dan Resensi Buku. Jakarta: Erlangga.

Longa, B.G. 2014. Pengembangan Bahan Ajar Membaca Cerpen dengan Ancangan Literasi Kritis. Tesis tidak diterbitkan. Malang: PPs UM.

Mubasiroh, S.L. 2016. Pengembangan Bahan Ajar Menulis Resensi Cerpen Berbasis Literasi Kritis bagi Siswa SMA Kelas XI. Tesis tidak diterbitkan. Malang: PPs UM.

Muslich, M. 2010. Text Book Writing: Dasar-Dasar Pemahaman, Penulisan, dan Pemakaian Buku Teks. Yogyakarta: Ar-Ruzz Media.

Pradopo, R.D. 2002. Kritik Sastra Indonesia Modern. Yogyakarta: Gama Media.

Pradopo, R.D. 2013. Beberapa Teori Sastra, Metode Kritik, dan Penerapannya. Yogyakarta: Pustaka Pelajar.

Prastowo, A. 2012. Panduan Kreatif Membuat Bahan Ajar Inovatif. Yogyakarta: Diva Press.

Priyatni, E.T. 2012. Membaca Sastra dengan Ancangan Literasi Kritis. Jakarta: Bumi Aksara.

Saddhono, K.\& Slamet, St.Y. 2014. Pembelajaran Keterampilan Berbahasa Indonesia dan Aplikasi. Edisi Kedua. Yogyakarta: Graha Ilmu.

Sitepu. 2012. Penulisan Buku Teks Pelajaran. Bandung: Remaja Rosdakarya. 